Article

\title{
Adsorption Strategy for Removal of Harmful Cyanobacterial Species Microcystis aeruginosa Using Chitosan Fiber
}

\author{
Yun Hwan Park ${ }^{1,+}$, Sok Kim ${ }^{1,2,+}$, Ho Seon Kim ${ }^{1}$, Chulhwan Park ${ }^{3, * \mathbb{D}}$ and Yoon-E Choi ${ }^{1, *}$ \\ 1 Division of Environmental Science \& Ecological Engineering, Korea University, Seoul 02841, Korea; \\ sug4393@korea.ac.kr (Y.H.P.); sokkim81@korea.ac.kr (S.K.); khs112@korea.ac.kr (H.S.K.) \\ 2 BK21 Plus Eco-Leader Education Center, Korea University, Seoul 02841, Korea \\ 3 Department of Chemical Engineering, Kwangwoon University, Seoul 01897, Korea \\ * Correspondence: chpark@kw.ac.kr (C.P.); yechoi@korea.ac.kr (Y.-EC.) \\ + The authors equally contributed to the present study.
}

Received: 17 April 2020; Accepted: 1 June 2020; Published: 4 June 2020

\begin{abstract}
Microcystis aeruginosa is one of the predominant species responsible for cyanobacterial-harmful algal blooms (Cyano-HABs) in water bodies. Cyano-HABs pose a growing number of serious threats to the environment and public health. Therefore, the demand for developing safe and eco-friendly solutions to control Cyano-HABs is increasing. In the present study, the adsorptive strategy using chitosan was applied to remove $M$. aeruginosa cells from aqueous phases. Using a simple immobilization process, chitosan could be fabricated as a fiber sorbent (chitosan fiber, $\mathrm{CF}$ ). By application of $\mathrm{CF}$, almost $89 \%$ of cyanobacterial cells were eliminated, as compared to those in the control group. Field emission scanning electron microscopy proved that the M. aeruginosa cells were mainly attached to the surface of the sorbent, which was correlated well with the measurement of the surface area of the fiber. We tested the hypothesis that massive applications of the fabricated CF to control Cyano-HABs might cause environmental damage. However, the manufactured CF displayed negligible toxicity. Moreover, we observed that the release of cyanotoxins and microcystins (MCs), during the removal process using $\mathrm{CF}$, could be efficiently prevented by a firm attachment of the $M$. aeruginosa cells without cell lysis. Our results suggest the possibility of controlling Cyano-HABs using a fabricated CF as a non-toxic and eco-friendly agent for scaled-up applications.
\end{abstract}

Keywords: harmful cyanobacterial blooms; HABs; Microcystis aeruginosa; chitosan; adsorption; biosorption; sorbent

\section{Introduction}

Cyanobacterial-harmful algal blooms (Cyano-HABs) have been observed in water bodies for over 130 years [1]. However, in recent decades, the inflow of nutrients [2-4] and climate change [1,5] has aggravated the extent and frequency of the occurrence of Cyano-HABs in water resources (e.g., lakes, rivers and reservoirs). Various harmful cyanobacterial species (e.g., Microcystis sp., Anabaena sp.) can lead to the formation of Cyano-HABs, and Microcystis aeruginosa has been recognized as one of the most prevalent bloom-forming and harmful cyanobacterial species in freshwater bodies. The overgrowth of harmful cyanobacterial cells in water bodies can cause serious damage, not only to the environment but also to human health. In a water environmental system, M. aeruginosa causes unpleasant odors and flavors, deoxygenizing the water column and unbalancing the water ecosystem, thereby killing other organisms [6,7]. Moreover, the M. aeruginosa cells can release a representative type of cyanotoxin, microcystins (MCs), into the water bodies following various types of physical, chemical and biological damage to the M. aeruginosa. MCs have been reported to cause severe 
hepatotoxicity, suppressing the proteins (phosphatase- 1 and $-2 \mathrm{~A}$, damaging the liver and promoting tumor growth [8]. Human exposure to MCs is manifested by ingestion, dermal contact and inhalation of MCs-contaminated water/aerosols [9]. Therefore, the Cyano-HABs treatment of water bodies is extremely important. Various treatments have been utilized, including several physical, chemical and biological methods. The following methods/reagents have been used to address the problems caused by Cyano-HABs: ultra-sonication [10], waterwheel system for water aeration [11,12], loess spraying [12], algicidal materials [13], coagulants [14] and algicidal bacteria [15]. Spraying loess into water bodies has been primarily employed to control Cyano-HABs in South Korea [12]. However, the aforementioned methods have several drawbacks; their application could cause severe damage to aquatic biota, lead to secondary contaminations and induce cyanotoxins during the Cyano-HABs treatment $[16,17]$. Therefore, novel technical solutions to control Cyano-HABs are desperately needed for the safe and sustainable management of water quality.

Adsorption is known as one of the prominent methods in the removal of various pollutants from water bodies [18]. One of the most remarkable advantages of the adsorption process is its selectivity attributed to fine-tuned adsorbents for target materials. Various adsorbents, including biosorbents (i.e., waste biomasses and biopolymers), can be modified and modulated by considering the properties of the target pollutants and adsorbents (i.e., characteristics of their functional groups). As such, adsorption technologies can be applied to control Cyano-HABs in water bodies. The M. aeruginosa is the target adsorbate herein, and it possesses several anionic functional groups [e.g., carboxyl ( $\mathrm{pK}_{\mathrm{a}}$ 3.9), phosphoryl ( $\left.\mathrm{pK}_{\mathrm{a}} 7.10\right)$, and hydroxyl $\left(\mathrm{pK}_{\mathrm{a}} 8-12\right)$ groups] and cationic functional groups (e.g., amine groups, $\mathrm{pK}_{\mathrm{a}}$ 8.6-9.0) on its surface [19]. These functional groups can be deprotonated, relying on the $\mathrm{pK}_{\mathrm{a}}$ properties of each functional group. As a result, the net surface charge of cyanobacteria cells will be negative in a natural aquatic solution, and the cells will attach to the positively charged surface of adsorbents by electrostatic interaction.

Chitosan is a well-known cationic biopolymer produced by the N-deacetylation of crab or shrimp chitin [20]. Owing to the abundant amine groups in its structure, as well as its non-toxicity, hydrophilicity, biodegradability, and its anti-bacterial nature, it has gained plenty of interest as an eco-friendly and efficient cationic adsorbent for the removal of anionic pollutants (metal, reactive dyes and protein) [21-24]. In addition, chitosan is reported to serve as an efficient flocculant for the removal of Cyano-HABs from water resources, due to its anionic properties. For example, Zou et al. [16] spread chitosan-treated local soil over Taihu lake to remove M. aeruginosa. They reported a cell removal efficiency that exceeded $90 \%$. Pei et al. [25] reported that $99 \%$ of the M. aeruginosa cells were removed from the water column by their integration of a chitosan flocculant. In cases where the entrapped $M$. aeruginosa cells were not removed from the water body, significant amounts of MCs were released due to the chitosan degradation and cell lysis [25]. Therefore, the overgrown M. aeruginosa cells and chitosan material with entrapped treated cells should be removed from water bodies as quickly as possible for sustainable management of water resources. However, the collection of entrapped $M$. aeruginosa cells is challenging due to the difficulty of collecting treated $M$. aeruginosa cells with used chitosan materials. Although the chitosan is a non-toxic and biodegradable material, the acidic condition of a chitosan solution sprayed over a water body for the control of M. aeruginosa can negatively influence water quality. Tiny chitosan particles (i.e., chitosan nanoparticles) can also cause physiological stress in aquatic biota [26]. Consequently, another approach is needed for using chitosan as a harmful cyanobacteria species controller.

This study proposes a new approach, based on the direct adsorption of the harmful cyanobacterial species M. aeruginosa using a chitosan-based sorbent. Chitosan can be simply designed in various shapes (e.g., beads, sheets, fibers) by an immobilization process in an alkalic solution. In this study, chitosan was converted into fiber form to ensure that a sufficient surface area of the sorbent is available for the treatment of targeted cells. Using the fabricated chitosan fiber (CF), the M. aeruginosa cell removal efficiency and behavior were evaluated in an aqueous medium. In addition, the acute toxicity levels of $\mathrm{CF}$ and the concentration of MCs were monitored during the entire treatment process, in order to 
determine the eco-safety of the sorption process in removing harmful cyanobacterial cells. The results of this study present an attainable and environment-friendly strategy that utilizes chitosan to control the Cyano-HABs in water bodies.

\section{Materials and Methods}

\subsection{Materials and Medium Components}

Low molecular weight chitosan (50,000-190,000 Da, deacetylated chitin) was purchased from Sigma Aldrich, Inc., Seoul, Korea. The acetic acid (>99.5\%) was acquired from Daejung Chemical \& Metals Co., Ltd., Siheung, Korea. The crosslinking agent, glutaraldehyde (GA, $25 \mathrm{wt} \%$ ), was obtained from Junsei Chemical Co., Ltd., Tokyo, Japan. Information about the chemicals that were used for the preparation of the BG11 medium is presented in Table S1 in the Supplemental Information. M. aeruginosa cells (isolated from Wangsong reservoir, Korea) were provided by Dr. Chi-Yong Ahn of the Korea Research Institute of Bioscience and Biotechnology (KRIBB, Daejeon, Korea).

\subsection{Preparation of Chitosan Fibers}

CFs were fabricated using a CS solution ( $6 \mathrm{wt} \%)$, by dissolving and stirring CS in a $5 \%$ acetic acid solution for $24 \mathrm{~h}$. The prepared CS solution was continuously injected into a $1 \mathrm{M} \mathrm{NaOH}$ solution by hub needles of different inner diameters using an air press. The inner diameters of hub needles are presented in Table S2 in the Supplemental Information. The fabricated CFs were deposited into $1 \mathrm{~mL} / \mathrm{L}$ of a GA solution (based on $1 \mathrm{M}$ of $\mathrm{NaOH}$ ) and stirred for $1 \mathrm{~h}$ for the crosslinking reaction. Afterward, CFs were separated from the solution and washed several times using distilled water to remove residual $\mathrm{NaOH}$ and GA. After washing, the sorbents were dried for 1 day in a freeze-dryer. Before the utilization of CFs for the cyanobacterial cell removal tests, CFs were sterilized by immersion in 70\% ethanol and UV irradiation for $10 \mathrm{~min}$. The sterilized CFs were dried for several hours on a clean bench.

\subsection{Analysis of Functional Groups}

The characteristics of the functional groups of CS and fabricated CFs were determined using a Fourier transform infrared spectrometer (FT-IR, Agilent Cary 630 FTIR, Agilent Technology, USA). The FT-IR spectra of the samples were measured using an attenuated total reflectance mode (ATR) in a wavelength range from 4000 to $700 \mathrm{~cm}^{-1}$.

\subsection{Determination of the Removal Potential of the Sorbent}

To determine the M. aeruginosa removal potential of CFs, the cyano-cells were cultivated with fabricated CFs in a batch system using BG11 medium. Preparation of the BG11 media followed the previously published protocol [27]. The chemicals and their contents are summarized in the Table S1 in the Supplemental Information. The medium $\mathrm{pH}$ was adjusted to approximately 7.1 using acetic acid solution prior to autoclaving. For the cell removal test, the M. aeruginosa inoculum (stationary stage) was moved to $150 \mathrm{~mL}$ of the fresh BG11 medium. Then, $0.3 \mathrm{~g}$ of the sterilized CF was added into the M. aeruginosa sample. The CF-suspended samples were incubated in controlled laboratory conditions (aeration of $0.15 \mathrm{~L} / \mathrm{min}$, light intensity of $50 \mu \mathrm{mol} / \mathrm{m}^{2}$, and temperature of $25^{\circ} \mathrm{C}$ ). The M. aeruginosa cells were also cultivated without any added CF under the same conditions to produce a control sample and determine the cell removal efficiency of CFs. During the experiments, the M. aeruginosa cells were counted under a microscope using a hemacytometer (Hausser Scientific, USA) at specific cultivation intervals $(4,8,12,18$ and $24 \mathrm{~h})$. All of the experiments were repeated three times under the same conditions. 


\subsection{Detection of Phosphorus and MCs}

During the test, phosphorus and MCs levels were analyzed to compare the cyanobacterial cell growth between the control and CF-treated sample. The Humas (Humas Co. Ltd., Korea) and Microcystins Plates ELISA (ALGALCHEM Inc., Taiwan) kits were utilized to estimate the concentration of phosphorus and MCs in the samples, respectively.

\subsection{Field Emission Scanning Electron Microscope (FE-SEM) Analysis}

After the cell removal test, FE-SEM analysis was conducted to determine the bound targeted $M$. aeruginosa cells on the CF surface. The CFs used before and after the cyanobacterial cell removal tests were prepared by freeze drying. The prepared CFs were coated using a $4 \mathrm{~nm}$ film of platinum that was applied in a vacuum chamber for $60 \mathrm{~s}$. Then, the coated CFs were scanned using the FE-SEM (Quanta 250 FEG, USA).

\subsection{Acute Toxicity Test with Daphnia magna}

Acute toxicity tests were conducted according to the EPA (Environmental Protection Agency) guideline [28] to determine the toxicity of CFs. Neonates of D. magna were aged for less than $24 \mathrm{~h}$ and used as per the guideline of the acute toxicity test with Daphnia magna Straus. For each toxicity test, $0.02 \mathrm{~g}$ of $\mathrm{CF}$ was inserted into each D. magna vessel (five D. magna specimens per sample). During the test, the $D$. magna samples were cultured under the following photoperiod conditions: $16 \mathrm{~h}$ of continuous light and $8 \mathrm{~h}$ of darkness at $20 \pm 2{ }^{\circ} \mathrm{C}$ for $48 \mathrm{~h}$. The tested D. magna were not fed during the test period. Immobilization (defined as no response to gentle agitation for $15 \mathrm{~s}$ ) of $D$. magna was determined at 24 and $48 \mathrm{~h}$ of cultivation time.

\subsection{Statistical Analysis}

To determine statistical significance between control and experimental data groups, $t$ test was conducted using a provided $t$ test function in the experimental data processing software (SigmaPlot 10.0).

\section{Results and Discussion}

\subsection{Property of Functional Groups on the Chitosan Fiber}

It is well known that chitosan possesses numerous amine groups as cationic binding sites in its molecular structure. These amine groups might be an important factor for the adsorption of the M. aeruginosa onto a sorbent. In order to check whether the main binding sites of the fabricated sorbent were denaturized during its manufacturing process, the prepared $\mathrm{CF}$ and raw material (i.e., chitosan powder) were analyzed by FT-IR. The FT-IR results of the sorbent and raw material are provided in Figure $\mathrm{S} 1$ in the Supplementary Information.

In the FT-IR spectrum of CF, various FT-IR peak characteristics could be observed at different wavelengths: $3360,3291,2921,2871,1646,1584,1420,1373,1318,1153,1064,1027$ and $893 \mathrm{~cm}^{-1}$. A strong band in the wavelength region $3360-3300 \mathrm{~cm}^{-1}$ was attributed to the $\mathrm{N}-\mathrm{H}$ and $\mathrm{O}-\mathrm{H}$ stretching [29]. The FT-IR peaks at approximately 2921 and $2871 \mathrm{~cm}^{-1}$ were ascribed to the symmetric and asymmetric $\mathrm{C}-\mathrm{H}$ stretching [30]. The residual $\mathrm{N}$-acetyl groups of $\mathrm{CF}$ were determined by the recorded bands at around $1646 \mathrm{~cm}^{-1}$ (the $\mathrm{C}=\mathrm{O}$ stretching of amide I) [31]. The IR peak at $1584 \mathrm{~cm}^{-1}$ marked the $\mathrm{N}-\mathrm{H}$ bending of the primary amine group of $\mathrm{CF}$ [32]. Further, $\mathrm{CH}_{2}$ bending and $\mathrm{CH}_{3}$ symmetrical deformation could be observed at 1420 and $1373 \mathrm{~cm}^{-1}$, respectively [33]. The C-N stretching (amide III groups) of the chitosan material was observed at $1318 \mathrm{~cm}^{-1}$ [34], and the peaks at 1153, 1064 and $1027 \mathrm{~cm}^{-1}$ represented the $\mathrm{C}-\mathrm{O}$ conjugation [35-37]. The observed peak at $1153 \mathrm{~cm}^{-1}$ was the FT-IR peak property for the $\mathrm{C}-\mathrm{O}-\mathrm{C}$ bridge [38]. As for the peaks at 1064 and $1027 \mathrm{~cm}^{-1}$, they were attributed to the $\mathrm{C}-\mathrm{O}$ stretching of the sorbents [39]. The peaks at $893 \mathrm{~cm}^{-1}$ corresponded to the $\mathrm{CH}$ bending out of the plane of the ring of monosaccharides [40]. In the FT-IR spectrum of CF, the peak at around 
$3360 \mathrm{~cm}^{-1}$, related to the $-\mathrm{NH}_{2}$ groups, showed a lower intensity than that of the chitosan powder. This could be explained by the fact that some of the $-\mathrm{NH}_{2}$ groups of chitosan were changed to $-\mathrm{N}=\mathrm{C}-$ by a crosslinking reaction between the amino groups and GA molecules [41]. In addition, the peaks indicating the $\mathrm{C}-\mathrm{H}$ stretching (2936 and $2871 \mathrm{~cm}^{-1}$ peaks) were enhanced when compared to those of the chitosan powder. This observation probably indicates that an increased number of GA molecules were present in CF due to the crosslinking reaction [42]. Although the crosslinking reaction occurred in $\mathrm{CF}$, the recorded FT-IR peaks were almost the same as those of the raw chitosan material. These results indicate that the manufacturing process for $\mathrm{CF}$ did not lead to any alterations in its chemical structure, and excluded any deformation of its main functional groups.

\subsection{Aeruginosa Removal Potential of Fabricated Sorbent}

According to our previous study [17], the extent of the amine groups retained on the adsorbent is critical for the $M$. aeruginosa cell adsorption, since the negatively charged cyanobacterial cells can be bound to the cationic amine groups by electrostatic interaction. The raw material (chitosan) chosen for this study is a well-known biopolymer, and is predominantly composed of numerous amine groups. Furthermore, the analysis of the functional group properties of the fabricated CF (made of chitosan) showed that the amine groups were present in the fabricated sorbent without any deterioration or denaturalization. Therefore, we hypothesized that CF might be suitable in the adsorptive removal of harmful cyanobacterial cells directly from an aqueous medium. To test this hypothesis, the M. aeruginosa removal potential of CFs was evaluated by comparing the growth profiles of the cyanobacterial cells cultured with and without CF in the BG11 medium, with an initial cell concentration of $(100.0 \pm 1.52) \times 10^{4}$ cells $/ \mathrm{mL}$. The control sample demonstrated the continuously increasing cell density of $M$. aeruginosa until it reached $(133.3 \pm 7.13) \times 10^{4}$ cells $/ \mathrm{mL}$ after $24 \mathrm{~h}$ (Figure 1 ). In contrast, the addition of CF suppressed the cyanobacterial cell growth. Thus, CF has the qualities of a biosorbent, and can remove the M. aeruginosa cells directly from the aqueous medium. In the CF-treated sample, the cell concentration of $M$. aeruginosa significantly decreased within the first $5 \mathrm{~h}$ of the treatment, as compared to its initial concentration. After $5 \mathrm{~h}$ of the treatment, the cell density slowly diminished and reached $(14.8 \pm 2.03) \times 10^{4}$ cells $/ \mathrm{mL}$ after $24 \mathrm{~h}$. Based on these results and taking into account the initial and control sample cell densities, the estimated removal efficiencies of CF were $85.2 \%$ and $88.9 \%$, respectively. To determine whether these results are statistically significant ( $\mathrm{p}$-value), a $t$ test was conducted using the control and experimental data groups. The p-value obtained from the statistical analysis was close to zero (0.0002). This indicates that the harmful cyanobacterial cells could be efficiently removed by the $\mathrm{CF}$ treatment.

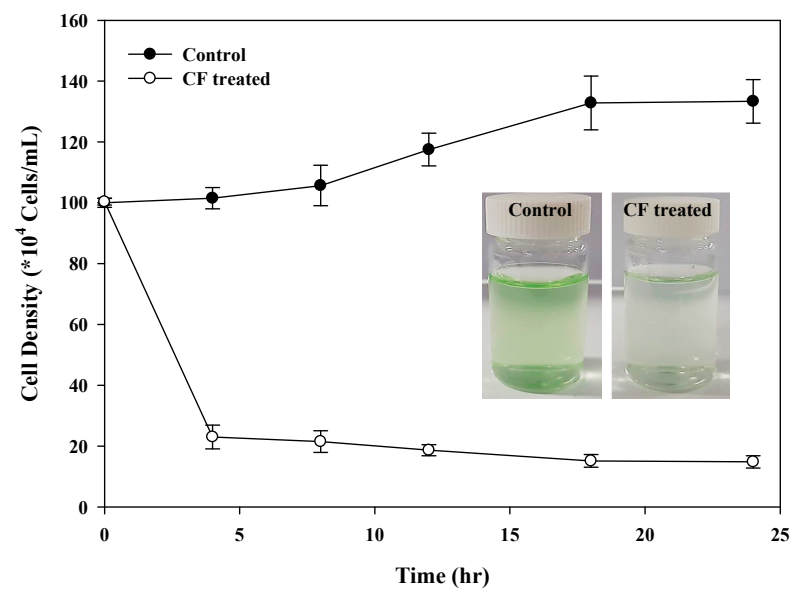

Figure 1. Removal of the M. aeruginosa cells using the fabricated chitosan fiber in BG11 medium. 
After the M. aeruginosa cell removal process, the color of CF dramatically changed from bright yellow to green (Figure S2).

The green color is observed due to a green pigment (chlorophylls) in the M. aeruginosa cells. The color change from bright yellow to green likely indicates that the cells were adsorbed by CF during the treatment. FE-SEM analysis was carried out later to determine the targeted cell adsorption by CF. As shown in Figure 2, the adsorbed M. aeruginosa cells are visible on the surface of CF after the treatment. Moreover, the adsorbed M. aeruginosa cells preserve their spherical shapes well. These results clearly indicate that the M. aeruginosa cells were adsorbed onto the CF surface without disruption and degradation.
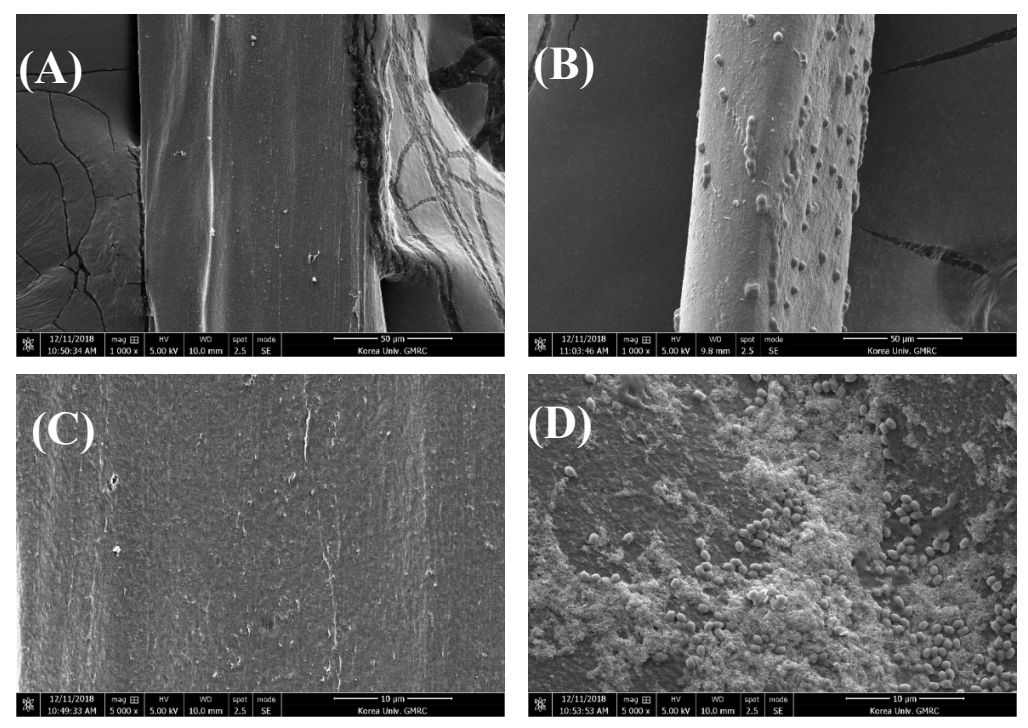

Figure 2. FE-SEM images of chitosan fibers before $(\mathbf{A}, \mathbf{C})$ and after $(\mathbf{B}, \mathbf{D})$ the $M$. aeruginosa treatment in BG11 medium. The magnifications are $\times 1000(\mathbf{A}, \mathbf{B})$ and $\times 5000(\mathbf{C}, \mathbf{D})$.

Furthermore, since phosphorus is an important limiting nutrient for cyanobacterial cell growth [43], its residual amount was monitored as indirect evidence of the M. aeruginosa cell control potential of $\mathrm{CF}$, by comparing phosphorus consumption between the control and experimental groups (Figure 3). Figure 3 shows that phosphorus consumption is higher in the control sample than it in the experimental sample. The consumed amount of phosphorus was $0.10 \pm 0.01 \mathrm{mg}$ in the control sample, whereas it equaled $0.06 \pm 0.001 \mathrm{mg}$ in the experimental one after the same period of cultivation $(24 \mathrm{~h})$. As mentioned above, phosphorus is an essential element of cyanobacterial cell growth, and the decreased use of phosphorus might indicate an inhibition of the growth activity of the cells adsorbed on the CF. In the control sample, the M. aeruginosa cells floated freely in the medium, and could use the phosphorus for their growth without any inhibition. However, in the experimental sample, the number of freely floating $M$. aeruginosa cells was significantly reduced as compared to that of the control sample, due to the cell adsorption onto the CF. At the same time, the phosphorus consumption of the cells attached to CF might be reduced as compared to that of the free cells, due to the inhibition of growth activity by aggregation. As a result, not only does the CF remove the M. aeruginosa cells from the aqueous solution by adsorption, but it also inhibits the growth of the cells adsorbed on the CF surface. 


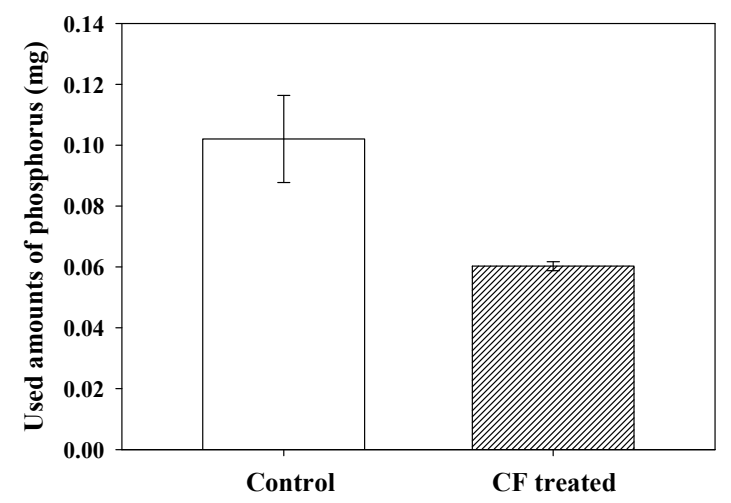

Figure 3. Phosphorus consumption in the control and CF-treated samples for $24 \mathrm{~h}$ of cultivation time. The initial amount of phosphorus in $150 \mathrm{~mL}$ of BG11 medium equaled $0.663 \pm 0.01 \mathrm{mg}$ (initial phosphorus concentration $=4.42 \pm 0.05 \mathrm{mg} / \mathrm{L})$.

\subsection{Safety Concerns for M. aeruginosa Removal Using Chitosan Fiber}

As stated above, CF is a feasible controller of the targeted cells and can be utilized for the direct treatment of Cyano-HABs in natural water bodies. However, various putative environmental factors of sorbents, including their toxicity, must be verified before their utilization in water bodies. To determine this, the toxicity of fabricated CF was evaluated using the acute toxicity test, by cultivating D. magna with CF according to the EPA guideline [28]. The toxicity test results for CF (Figure 4A) showed that the survival rates of $D$. magna were not significantly affected by the presence of $C F$; this result was achieved by using the same concentration of CF that was applied in the M. aeruginosa cell removal test. After 24 and $48 \mathrm{~h}$ of cultivation time, the survival rates of D. magna were $97.5 \% \pm 7.07 \%$ and $95 \% \pm 9.26 \%$, respectively, as compared to those of the control sample $(100 \%)$. These results indicate that CF did not cause any toxicity.
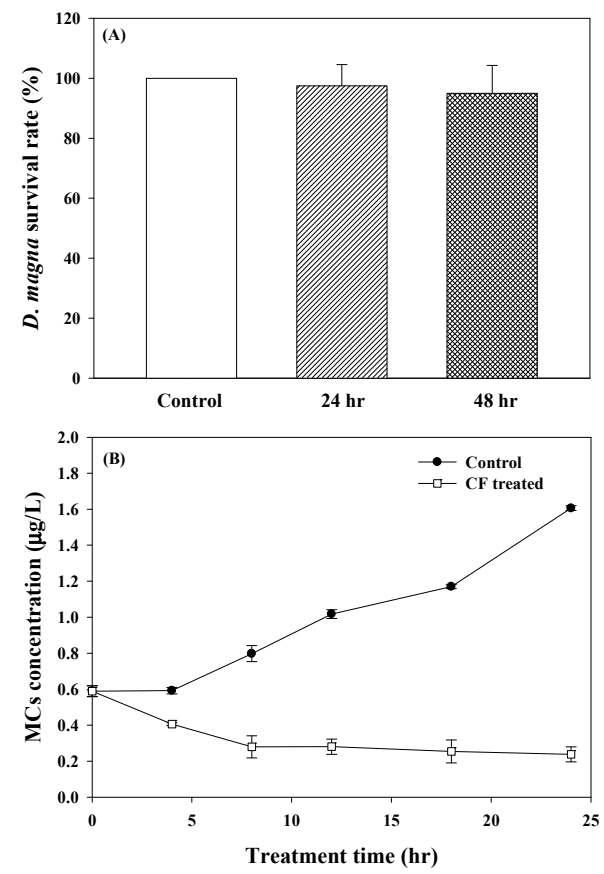

Figure 4. Survival rates of Daphnia magna cultivated with the chitosan fiber sample (A) and the detected microcystins (MCs) (B) in the control and experimental samples during the M. aeruginosa control process. 
Another important safety consideration for the adsorption M. aeruginosa is the possible discharge of cyanotoxins (MCs) during the removal process. According to Pietsch et al. [44], M. aeruginosa could accelerate the release of MCs into water bodies via cell destruction due to physical and biological factors. Although CF is a non-toxic adsorbent and is capable of removing cyanobacterial cells with minimal cell damage, there is a risk of toxin emission by the decomposition of cells (in the medium or on $\mathrm{CF}$ ), due to various unexpected factors. Therefore, the amount of MCs in the control and CF-treated samples was thoroughly analyzed (Figure 4B). The concentration of MCs in the control sample continuously increased from $0.59 \pm 0.03 \mu \mathrm{g} / \mathrm{L}$ to $1.61 \pm 0.01 \mu \mathrm{g} / \mathrm{L}$ during their cultivation without CF. On the contrary, in the CF-treated sample, the concentration of MCs decreased to $0.24 \pm 0.04 \mu \mathrm{g} / \mathrm{L}$ during the treatment period. The significance between the control and experimental data groups was estimated as 0.004 ( $\mathrm{p}$ value) by the statistical $t$ test. The decreased concentration of MCs in the CF-treated sample is explained by the adsorption of MCs by CF. The $\mathrm{pK}_{\mathrm{a}}$ properties of MCs, especially that of MC-LR, were determined to be 2.09, 2.19 and 12.48, for two carboxylic groups and one free amino group, respectively [45]. Due to the activation of the anionic positions of MCs by the deprotonation reaction in the range $\mathrm{pH}$ 7.6 7.8 during the cell removal process, MCs can also be negatively charged and attracted to the cationic binding sites in CF by electrostatic attraction. Thus, the CF-based methodology can be suggested as an eco-friendly and safe option for the control of Cyano-HABs in water resources.

\subsection{Size Effect of the Chitosan Sorbents on the M. aeruginosa Removal Efficiency}

FE-SEM results showed that the removed $M$. aeruginosa cells were exclusively located on the surface of the utilized CF because their cell sizes were too large to be transported into the CF matrix. Due to the difference in the contact probability between the cyanobacterial cells and the binding position of the adsorbents, the surface area of the sorbent is believed to be important for sorption performances. Since thickness is an essential factor for the determination of the CF's surface area, to assess the surface size effect of CFs on the adsorptive removal of M. aeruginosa in detail, the fabricated CFs with different thicknesses were utilized for the cyanobacterial cell removal test. The detailed size characteristics of the utilized CFs are summarized in Table S2 in the Supplemental Information. The thicknesses of the CFs (CF1-CF4) used for the M. aeruginosa removal test were $0.286 \pm 0.028,0.192 \pm 0.022,0.098 \pm 0.022$ and $0.04 \pm 0.004 \mathrm{~mm}$, respectively. Figure 5 represents the cyanobacterial cell removal efficiency for each $\mathrm{CF}$, and shows negative linear correlation between the thickness of the $\mathrm{CF}$ and its cell removal rates. The removal efficiencies of CFs (from CF1 to CF4) were calculated by comparing the values with the initial cell density, and were determined to be $43 \% \pm 9.9 \%, 56 \% \pm 3.9 \%, 67 \% \pm 1.9 \%$ and $73.7 \% \pm 3.3 \%$, respectively. The cyanobacterial cell densities were also compared between the experimental and control groups after $24 \mathrm{~h}$ of the treatment time. The cell removal efficiencies of CF1-CF4 were calculated as $70.6 \% \pm 5.2 \%, 77.28 \% \pm 2.1 \%, 83.0 \% \pm 1.0 \%$ and $86.4 \% \pm 1.7 \%$, respectively. In all cases, the determination coefficient of linear fits $\left(\mathrm{R}^{2}\right)$ equaled 0.991 . To further compare the surface areas of CFs, it was assumed that the volume used for each CF in the cyanobacterial cell control test was the same $\left(V_{\text {assumed }}=\right.$ constant value $)$, as the manufactured $C F$ s were made of the same chitosan solution, and their densities were, in all probability, equal. The surface areas of the CFs were calculated using their thickness and equally assumed volume. According to Table S2, the surface area of a CF increased as its thickness decreased. As such, the surface areas of CF2, CF3 and CF4 were 1.48, 2.88 and 7.04 times more than that of CF1, respectively. Consequently, the cyanobacteria removal efficiencies of $\mathrm{CFs}$ were observed to become higher with an increase in their surface area. 


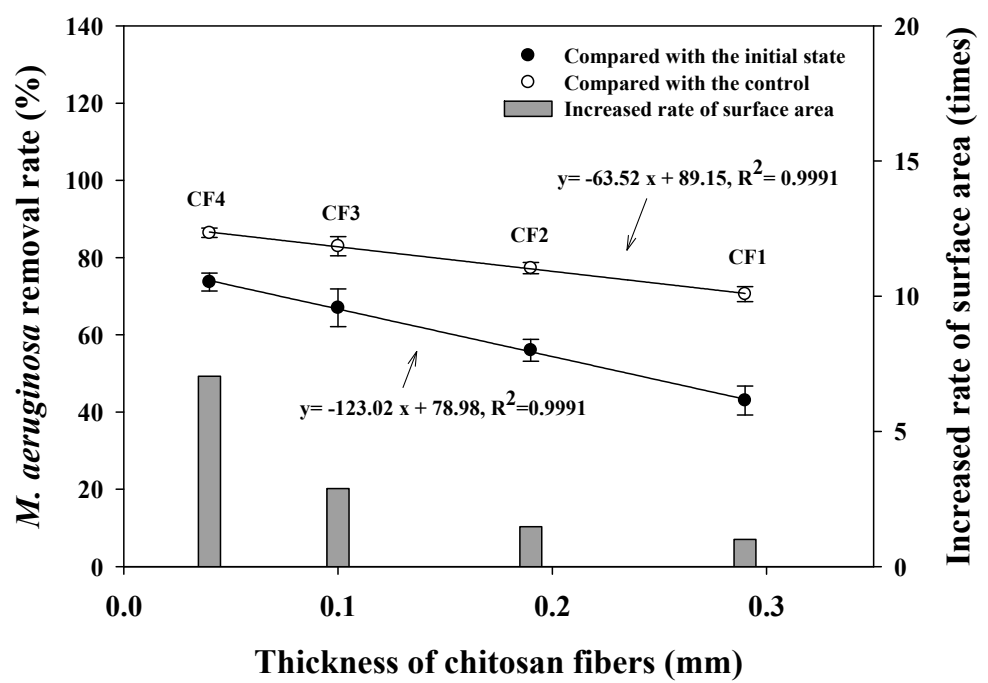

Figure 5. M. aeruginosa removal efficiencies using different thicknesses of chitosan fibers.

\subsection{Conventional and New Applications of Chitosan}

The utilization of chitosan as a coagulant and flocculation agent has been deemed efficient for the control of $M$. aeruginosa populations $[25,46,47]$. However, the conventional application of chitosan to water bodies requires additional processes to be established for the recovery of the aggregated cyanobacterial cells after the treatment. This is due to the risk of discharging cyanotoxins from the aggregated cell lysis. In addition, after the application of chitosan as a coagulant, it can cause excessive cyanobacterial cell sedimentation to the bottom water. Thus, during the recovery of the treated cyanobacterial cells, or their upwelling, the bottom sediments contaminated with toxic pollutants can float to the water surface or stay within the water column. The treatment approach suggested herein is designed to overcome the aforementioned issues. The chitosan immobilized in a fiber form can be easily packed into various porous containers and applied to the water surface, to control Cyano-HABs by immersion in a static water body. In addition, before cell lysis and the biodegradation of the sorbent, the immobilized chitosan in containers can be recovered much easier and faster than the case of utilizing chitosan (powder or solution) as a coagulant after Cyano-HABs treatment. The immobilized fibrous chitosan displays a high removal efficiency of the cyanobacterial cells (almost 90\%), and non-toxic properties. Therefore, the utilization of chitosan fiber is a feasible way to control harmful cyanobacterial species in water resources.

\section{Conclusions}

Herein, a cationic biopolymer (chitosan) was fabricated in its fiber form via a simple immobilization process. We investigated its usage as a sorbent for the direct removal of harmful cyanobacteria species (M. aeruginosa) from an aquatic medium. CF presented the high cyanobacterial cell removal efficiency of almost $90 \%$, in comparison to the control set. The cell removal efficiency was influenced by CF surface area. After the treatment process, the CF's color changed from yellow to green. FE-SEM observations revealed that the M. aeruginosa cells were probably adsorbed onto the CF surface without any cell damage. The acute toxicity test using $D$. magna showed that the toxicity of $C F$ was negligible. In addition, during the M. aeruginosa cell growth, the concentration of cyanotoxins (MCs) in the control sample increased from $0.59 \pm 0.03 \mu \mathrm{g} / \mathrm{L}$ to $1.61 \pm 0.01 \mu \mathrm{g} / \mathrm{L}$. However, the MC discharge could be prevented in the CF-treated sample. Based on these results, CF may be a safe and eco-friendly solution to controlling Cyano-HABs in water resources. 
Supplementary Materials: The following are available online at http://www.mdpi.com/2071-1050/12/11/4587/s1, Figure S1: The FT-IR spectrum of (A) raw chitosan powder and (B) manufactured chitosan fiber, Figure S2: The color change of applied chitosan fiber (A) before and (B) after treatment of M. aeruginosa cells, Table S1: Chemical components for BG 11 media, Table S2: Size information of the utilized CFs for removal of M. aeruginosa.

Author Contributions: Conceptualization, S.K. and Y.H.P.; Methodology, Y.H.P.; Validation, S.K., Y.-EC., and C.P.; Formal Analysis, Y.H.P. and H.S.K.; Investigation, Y.H.P. and H.S.K.; Resources, Y.H.P. and H.S.K.; Data Curation, Y.H.P.; Writing: Original Draft Preparation, Y.H.P.; Writing: Review \& Editing, S.K. and Y.-EC.; Visualization, Y.H.P. and S.K.; Supervision, S.K., C.P., and Y.-EC.; Project Administration, Y.-EC. and S.K.; Funding Acquisition, Y.-EC. and S.K. All authors have read and agreed to the published version of the manuscript.

Funding: This study was financially supported by the OJeong Eco-Resilience Institute (OJERI) and BK21 Plus Eco-leader Education Center (ELEC) of the Korea University. The grants provided by the National Research Foundation of Korea (Grant No.: 2018R1A6A3A11045442 and 2019R1A2C2087449) supported this study.

Conflicts of Interest: The authors declare no conflict of interest in this study.

\section{References}

1. O'neil, J.; Davis, T.; Burford, M.; Gobler, C. The rise of harmful cyanobacteria blooms: The potential roles of eutrophication and climate change. Harmful Algae 2012, 14, 313-334. [CrossRef]

2. Paerl, H.W.; Xu, H.; McCarthy, M.J.; Zhu, G.; Qin, B.; Li, Y.; Gardner, W.S. Controlling harmful cyanobacterial blooms in a hyper-eutrophic lake (Lake Taihu, China): The need for a dual nutrient (N \& P) management strategy. Water Res. 2011, 45, 1973-1983. [PubMed]

3. Xu, H.; Paerl, H.; Qin, B.; Zhu, G.; Hall, N.; Wu, Y. Determining critical nutrient thresholds needed to control harmful cyanobacterial blooms in eutrophic Lake Taihu, China. Environ. Sci. Technol. 2015, 49, 1051-1059. [CrossRef] [PubMed]

4. Paerl, H.W.; Havens, K.E.; Hall, N.S.; Otten, T.G.; Zhu, M.; Xu, H.; Zhu, G.; Qin, B. Mitigating a global expansion of toxic cyanobacterial blooms: Confounding effects and challenges posed by climate change. Mar. Freshw. Res. 2020, 71, 579-592. [CrossRef]

5. Paerl, H.W.; Gardner, W.S.; Havens, K.E.; Joyner, A.R.; McCarthy, M.J.; Newell, S.E.; Qin, B.; Scott, J.T. Mitigating cyanobacterial harmful algal blooms in aquatic ecosystems impacted by climate change and anthropogenic nutrients. Harmful Algae 2016, 54, 213-222. [CrossRef]

6. Merel, S.; Walker, D.; Chicana, R.; Snyder, S.; Baurès, E.; Thomas, O. State of knowledge and concerns on cyanobacterial blooms and cyanotoxins. Environ. Int. 2013, 59, 303-327. [CrossRef]

7. Paerl, H.W.; Fulton, R.S.; Moisander, P.H.; Dyble, J. Harmful freshwater algal blooms, with an emphasis on cyanobacteria. Sci. World J. 2001, 1, 76-113. [CrossRef]

8. Wang, S.L.; Wang, L.L.; Ma, W.H.; Johnson, D.M.; Fang, Y.F.; Jia, M.K.; Huang, Y.P. Moderate valence band of bismuth oxyhalides (BiOXs, $\mathrm{X}=\mathrm{Cl}, \mathrm{Br}, \mathrm{I}$ ) for the best photocatalytic degradation efficiency of MC-LR. Chem. Eng. J. 2015, 259, 410-416. [CrossRef]

9. Cheng, Y.S.; Zhou, Y.; Irvin, C.M.; Kirkpatrick, B.; Backer, L.C. Characterization of aerosols containing microcystin. Mar. Drugs 2007, 5, 136-150. [CrossRef]

10. Park, J.; Son, Y.; Lee, W.H. Variation of efficiencies and limits of ultrasonication for practical algal bloom control in fields. Ultrason. Sonochem. 2019, 55, 8-17. [CrossRef]

11. Chen, X.; He, S.; Huang, Y.; Kong, H.; Lin, Y.; Li, C.; Zeng, G. Laboratory investigation of reducing two algae from eutrophic water treated with light-shading plus aeration. Chemosphere 2009, 76, 1303-1307. [CrossRef] [PubMed]

12. Choi, H.-J.; Lee, S.-Y. Use of hybrid microcapsules, chitosan-methyl esterified sericite-tannin, for the removal of harmful lake algae and nutrient. Environ. Technol. 2020, 41, 822-831. [CrossRef] [PubMed]

13. Kinley, C.M.; Iwinski, K.J.; Hendrikse, M.; Geer, T.D.; Rodgers, J.H., Jr. Cell density dependence of Microcystis aeruginosa responses to copper algaecide concentrations: Implications for microcystin-LR release. Ecotoxicol. Environ. Saf. 2017, 145, 591-596. [CrossRef] [PubMed]

14. Martínez, T.d.C.C.; Rodríguez, R.A.; Voltolina, D.; Morquecho, L. Effectiveness of coagulants-flocculants for removing cells and toxins of Gymnodinium catenatum. Aquaculture 2016, 452, 188-193. [CrossRef]

15. Li, Y.; Liu, L.; Xu, Y.; Li, P.; Zhang, K.; Jiang, X.; Zheng, T.; Wang, H. Stress of algicidal substances from a bacterium Exiguobacterium sp. h10 on Microcystis aeruginosa. Lett. Appl. Microbiol. 2017, 64, 57-65. [CrossRef] 
16. Zou, H.; Pan, G.; Chen, H.; Yuan, X. Removal of cyanobacterial blooms in Taihu Lake using local soils II. Effective removal of Microcystis aeruginosa using local soils and sediments modified by chitosan. Environ. Pollut. 2006, 141, 201-205. [CrossRef]

17. Kim, S.; Jeon, M.S.; Kim, J.Y.; Sim, S.J.; Choi, J.-S.; Kwon, J.; Choi, Y.-E. Adsorptive removal of harmful algal species Microcystis aeruginosa directly from aqueous solution using polyethylenimine coated polysulfone-biomass composite fiber. Biodegradation 2018, 29, 349-358. [CrossRef]

18. Kim, S.; Won, S.W.; Cho, C.-W.; Yun, Y.-S. Valorization of Escherichia coli waste biomass as a biosorbent for removing reactive dyes from aqueous solutions. Desalin. Water Treat. 2016, 57, 20084-20090. [CrossRef]

19. Hadjoudja, S.; Deluchat, V.; Baudu, M. Cell surface characterisation of Microcystis aeruginosa and Chlorella vulgaris. J. Colloid Interface Sci. 2010, 342, 293-299. [CrossRef]

20. Hirano, S. Chitin and chitosan as novel biotechnological materials. Polym. Int. 1999, 48, 732-734. [CrossRef]

21. Wu, F.-C.; Tseng, R.-L.; Juang, R.-S. Comparative adsorption of metal and dye on flake-and bead-types of chitosans prepared from fishery wastes. J. Hazard. Mater. 2000, 73, 63-75. [CrossRef]

22. Juang, R.-S.; Wu, F.-C.; Tseng, R.-L. Solute adsorption and enzyme immobilization on chitosan beads prepared from shrimp shell wastes. Bioresour. Technol. 2001, 80, 187-193. [CrossRef]

23. Song, M.-H.; Kim, S.; Reddy, D.H.K.; Wei, W.; Bediako, J.K.; Park, S.; Yun, Y.-S. Development of polyethyleneimine-loaded core-shell chitosan hollow beads and their application for platinum recovery in sequential metal scavenging fill-and-draw process. J. Hazard. Mater. 2017, 324, 724-731. [CrossRef]

24. Sierra-Trejo, P.V.; Guibal, E.; Louvier-Hernández, J.F. Arsenic sorption on chitosan-based sorbents: Comparison of the effect of molybdate and tungstate loading on As (V) sorption properties. J. Polym. Environ. 2020, 1-14. [CrossRef]

25. Pei, H.-Y.; Ma, C.-X.; Hu, W.-R.; Sun, F. The behaviors of Microcystis aeruginosa cells and extracellular microcystins during chitosan flocculation and flocs storage processes. Bioresour. Technol. 2014, 151, 314-322. [CrossRef]

26. Hu, Y.-L.; Qi, W.; Hna, F.; Shao, J.-Z.; Gao, J.-Q. Toxicity evaluation of biodegradable chitosan nanoparticles using a zebrafish embryo model. Int. J. Nanomed. 2011, 6, 3351-3359.

27. Yu, X.; Zhou, J.; Wang, Z.; Cai, W. Preparation of visible light-responsive AgBiO(3) bactericide and its control effect on the Microcystis aeruginosa. J. Photochem. Photobiol. B 2010, 101, 265-270. [CrossRef]

28. Weber, C.I. (Ed.) Methods for Measuring the Acute Toxicity of Effluents to Freshwater and Marine Organisms; EPA/600/4-90./027F; Environmental Monitoring System Laboratory, U.S. Environmental Protection Agency: Cincinnati, OH, USA, 1993.

29. Rahman, N.A.; Hanifah, S.A.; Mobarak, N.N.; Su'ait, M.S.; Ahmad, A.; Shyuan, L.K.; Khoon, L.T. Synthesis and characterizations of o-nitrochitosan based biopolymer electrolyte for electrochemical devices. PLOS ONE 2019, 14, e0212066. [CrossRef]

30. Jayaramudu, T.; Varaprasad, K.; Pyarasani, R.D.; Reddy, K.; Kumar, K.D.; Akbari-Fakhrabadi, A.; Mangalaraja, R.V.; Amalraj, J. Chitosan capped copper oxide/copper nanoparticles encapsulated microbial resistant nanocomposite films. Int. J. Biol. Macromol. 2019, 128, 499-508. [CrossRef]

31. Trung, T.S.; Van Tan, N.; Van Hoa, N.; Minh, N.C.; Loc, P.T.; Stevens, W.F. Improved method for production of chitin and chitosan from shrimp shells. Carbohydr. Res. 2020, 489, 107913. [CrossRef]

32. Lei, Y.; He, J.; Zhao, Q.; Liu, T. A nitrile functionalized graphene filled ethylene propylene diene terpolymer rubber composites with improved heat resistance. Compos. Part. B Eng. 2018, 134, 81-90. [CrossRef]

33. Perevalov, V.P.; Mityanov, V.S.; Lichitsky, B.V.; Komogortsev, A.N.; Kuz'mina, L.G.; Koldaeva, T.Y.; Miroshnikov, V.S.; Kutasevich, A.V. Synthesis of highly functional imidazole derivatives via assembly of 2-unsubstituted imidazole N-oxides with $\mathrm{CH}$-acids and arylglyoxals. Tetrahedron 2020, 76, 130947. [CrossRef]

34. Khalid, N.; Bibi, A.; Akhtar, K.; Mustafa, K.; Khan, M.; Saeed, N. New blue light emissive polyazomethine(s) containing bromo-triphenyl units: Synthesis and photophysics. Polym-Plast Technol. Mater. 2019, 58, 419-426. [CrossRef]

35. Idowu, A.B.; Oluwabunmi, O.O.; Adewole, A.A. Evaluating the functional groups in a novel instant "Ogi" produced from maize grains with fermentation starter using fourier transform infrared (FTIR) technique. Am. J. Food Sci. Health 2020, 6, 32-42. 
36. Zięba-Palus, J.; Trzcińska, B.; Wesełucha-Birczyńska, A.; Moskal, P.; Sacharz, J. The sequence of changes observed during degradation process of paper by the use of UV/VIS and FTIR spectrometry with application of the PCA and 2D correlation method for forensic purposes. J. Mol. Struct. 2020, 1205, 127651. [CrossRef]

37. Rahman, A.; Zhou, Q.; Lin, X. Asymmetric organocatalytic synthesis of chiral 3,3-disubstituted oxindoles via a 1,6-conjugate addition reaction. Organ. Biomol. Chem. 2018, 16, 5301-5309. [CrossRef]

38. Yin, X.; Huang, A.; Zhang, S.; Liu, R.; Ma, F. Identification of three Dalbergia species based on differences in extractive components. Molecules 2018, 23, 2163. [CrossRef]

39. Cai, H.; Du, F.; Li, L.; Li, B.; Li, J.; Shi, H. A practical approach based on FT-IR spectroscopy for identification of semi-synthetic and natural celluloses in microplastic investigation. Sci. Total Environ. 2019, 669, 692-701. [CrossRef]

40. Salehi, E.; Emam-Djomeh, Z.; Askari, G.; Fathi, M. Opuntia ficus indica fruit gum: Extraction, characterization, antioxidant activity and functional properties. Carbohydr. Polym. 2019, 206, 565-572. [CrossRef]

41. Islam, N.; Dmour, I.; Taha, M.O. Degradability of chitosan micro/nanoparticles for pulmonary drug delivery. Heliyon 2019, 5, e01684. [CrossRef]

42. Gupta, K.C.; Jabrail, F.H. Effect of molecular weight and degree of deacetylation on controlled release of isoniazid from chitosan microspheres. Polym. Adv. Technol. 2008, 19, 432-441. [CrossRef]

43. Okada, M.; Sudo, R.; Aiba, S. Phosphorus uptake and growth of blue-green alga, Microcystis aeruginosa. Biotechnol. Bioeng. 1982, 24, 143-152. [CrossRef] [PubMed]

44. Pietsch, J.; Bornmann, K.; Schmidt, W. Relevance of intra-and extracellular cyanotoxins for drinking water treatment. Acta hydrochim. Hydrobiolog. 2002, 30, 7-15. [CrossRef]

45. He, X.; Pelaez, M.; Westrick, J.A.; O’Shea, K.E.; Hiskia, A.; Triantis, T.; Kaloudis, T.; Stefan, M.I.; de la Cruz, A.A.; Dionysiou, D.D. Efficient removal of microcystin-LR by UV-C/H2O2 in synthetic and natural water samples. Water Res. 2012, 46, 1501-1510. [CrossRef] [PubMed]

46. Capelete, B.; Brandão, C. Evaluation of trihalomethane formation in treatment of water containing Microcystis aeruginosa using chitosan as coagulant. Water Sci. Technol. Water Supply 2013, 13, 1167-1173. [CrossRef]

47. Li, L.; Zhang, H.; Pan, G. Influence of zeta potential on the flocculation of cyanobacteria cells using chitosan modified soil. J. Environ. Sci. 2015, 28, 47-53. [CrossRef] [PubMed] 